\title{
Etika Guru Menurut Perspektif Pendidikan Agama Islam
}

\author{
Yazidul Busthomi \\ Program Studi Pendidikan Agama Islam \\ Institut Agama Islam Al-Qolam Gondanglegi Malang, Indonesia \\ Email: busthomi@alqolam.ac.id \\ Syamsul A'dlom \\ Program Studi Pendidikan Agama Islam \\ Institut Agama Islam Al-Qolam Gondanglegi Malang, Indonesia \\ Email: samsuladlom06@gmail.com
}

\begin{abstract}
According to the term, the language of ethics comes from the word ethos which means customs (habits), while in terms of ethics is the study of human behavior to determine the values of good and bad deeds, while the measure to determine the value is the human mind or resio. Ethics is a whole of norms and judgments that are used by the society concerned to find out how humans should live their lives in a rational way. Ethics functions as an appraiser, determinant, determinant of an action carried out by humans, thus ethics plays a more role as a drafter of behavior carried out by humans. Among teacher ethics according to the perspective of Islamic religious education, namely: 1. Accepting questions raised by students, 2. Not rushing in all matters, 3. Sitting with dignity with calmness and bowing your head, 4. Not being arrogant to all humans, 5. Prioritizing tawadu 'in meeting places and assemblies, 6. Not playing and joking, 7. Showing affection for students when teaching.
\end{abstract}

Keywords: Ethics, Teacher, Islam

\section{Pendahuluan}

Para ahli menilai pendidikan memiliki peran penting dalam upaya menanamkan rasa keagamaan pada seorang anak (Jalaluddin, 2017, p.251). Kemudian, melalui pendidikan pula dilakukan pembentukan sikap keagamaan tersebut. Pendidikan itu mulai ada sejak adanya manusia yang pertama yaitu Nabi Adam. Sebagaimana yang dijelaskan dalam al-Qur'an surat alBaqarah ayat 31 yaitu:

$$
\text { و علّم ادم الاسماء كلها ثم عرضهم على الملئكة فقال انبؤني باسماء هؤلاء ان كنتم صدقين }
$$

Dan Dia (Allah) mengajarkan kepada Adam nama-nama (benda-benda) seluruhnya, kemudian mengemukakannya kepada para malaikat lalu berfirman: sebutkanlah kepada-Ku nama benda-benda itu jika kamu memang benar-benar orang yang benar.

Pendidikan adalah suatu aktivitas untuk mengembangkan seluruh aspek kepribadian manusia yang berjalan seumur hidup (Zuhairini, 2015, p.149). Dengan kata lain pendidikan tidak hanya berlangsung di dalam kelas, tetapi berlangsung pula di luar kelas. Pendidikan bukan bersifat formal saja, tetapi mencakup pula yang nonformal dan informal. Pendidikan tidak 


\section{Yazidul Busthomi, Syamsul A'dlom}

identik dengan pengajaran yang hanya terbatas pada usaha mengembangkan intelektualitas manusia. Tugas pendidikan bukan hanya meningkatkan kecerdasan, melainkan mengembangkan seluruh aspek kepribadian manusia. Pendidikan merupakan sarana utama untuk mengembangkan kepribadian setiap manusia.

Pendidikan pada hakikatnya adalah pengembangan potensi atau kemampuan manusia secara menyeluruh yang pelaksanaannya dilakukan dengan cara mengajarkan pelbagai pengetahuan dan kecakapan yang dibutuhkan oleh manusia itu sendiri (Muhibbin Syah, 2018, p.35). Dalam perspektif psikologi, pelatihan sebenarnya masih berada dalam ruang lingkup pengajaran. Artinya, pelatihan adalah salah satu unsur pelaksanaan proses pengajaran kerampilan ranah karsa. Selain pengajaran dan pelatihan, dalam pendidikan juga diperlukan bimbingan.

Pendidikan bermaksud membantu peserta didik untuk menumbuh kembangkan potensipotensi kemanusiaannya (Umar Tirtarahardja dan La Sulo, 2015, p.1). Potensi kemanusiaan merupakan benih kemungkinan untuk menjadi manusia. Ibarat biji mangga bagaimanapun wujudnya jika ditanam dengan baik, pasti menjadi pohon mangga dan bukannya menjadi pohon pisang.

Bagi bangsa Indonesia, pendidikan diartikan sebagai perjuangan bangsa (Muzayyin Arifin, 2018, p.73). Yaitu pendidikan yang berakar pada kebudayaan bangsa Indonesia dan yang berdasarkan pancasiala dan UUD 1945. Dalam operasionalnya, pendidikan nasioanal dikelompokkan ke dalam berbagai jenis sesuai dengan sifat dan kekhususan tujuannya.

Operasional yang dikelola sesuai tahapan atau tingkat perkembangan peserta didik dan kelulusannya.

Pendidikan nasional bertujuan mencerdaskan kehidupan bangsa dan mengembangkan manusia Indonesia seutuhnya (Soetjipto dan Raflis kosasi, 2019, p.59). Yaitu manusi yang beriman dan bertakwa terhadap Tuhan yang maha esa dan berbudi pekerti luhur, memiliki pengetahuan dan ketrampilan, kepribadian yang mantab dan mandiri, serta tanggung jawab kemasyarakatan dan kebangsaan.

Pendidikan dipercaya sebagai alat strategis meningkatkan taraf hidup manusia. Melalui pendidikan manusia menjadi cerdas, memiliki skill, sikap hidup yang baik sehingga dapat bergaul dengan baik pula di masyarakat dan dapat menolong dirinya sendiri, keluarga dan masyarakat. Pendidikan menjadi investasi yang memberi keuntungan sosial dan pribadi yang 
menjadikan bangsa bermartabat dan menjadikan individunya menjadi manusia yang memiliki derajat (Engkoswara dan Aan Komariah, 2015, p.1).

Penyelenggaraan pendidikan agama setelah Indonesia merdeka mendapat perhatian serius dari pemerintah (Samsul Nizar, 2018, p.345). Kedudukan pendidikan Islam dalam sistem pendidikan nasional ada kalanya sebagai mata pelajaran dan adakala sebagai lembaga (Ramayulis, 2008, p.41).

Esensi pendidikan agama Islam terletak pada kemampuannya untuk mengembangkan potensi siswa agar menjadi manusia yang beriman dan bertakwa dan dapat tampil sebagai khalifatullah fi al-ardh. Esensi ini menjadi acuan terhadap metode pembelajaran untuk mencapai tujuan yang maksimal (Ismail, 2019, p.3).

Pendidikan adalah usaha sadar terencana untuk mewujudkan suasana belajar dan proses pembelajaran agar peserta didik secara aktif mengembangkan potensi dirinya untuk memiliki kekuatan spritual keagamaan, pengendalian diri, kepribadian, kecerdasan, akhlak mulia, serta keterampilan yang diperlukan darinya, masyarakat, bangsa, dan Negara. Fungsi dan tujuan pendidikan sebagaimana yang tercantum dalam UU No. 20 tentang Sistem Pendidikan Nasional tahun 2003 dinyatakan pada pasal 3 yaitu: Pendidikan nasional berfungsi mengembangkan kemampuan dan membentuk watak serta peradaban bangsa yang bermartabat dalam rangka mencerdaskan kehidupan bangsa, bertujuan untuk berkembangnya potensi peserta didik agar manjadi manusia yang beriman dan bertaqwa kepada Tuhan Yang Maha Esa, berakhlak mulia, sehat, berilmu, cakap, kreatif, mandiri, dan menjadi warga negara yang demokratis serta bertanggungjawab.

Hakikat pendidikan etika dalam Islam adalah menumbuh kembangkan sikap manusia agar menjadi lebih sempurna secara moral, sehingga hidupnya selalu terbuka bagi kebaikan dan tertutup dari segala macam keburukan dan menjadi manusia berakhlak. Etika adalah suatu tabiat atau sifat seseorang, yakni keadaan jiwa yang telah terlatih, sehingga dalam jiwa tersebut benar-benar telah melekat sifat-sifat yang melarhirkan perbuatan-perbuatan dengan mudah dan spontan tanpa dipikirkan dan diangan-angan lagi. Kedudukan etika dalam kehidupan manusia menempati tempat yang penting, baik sebagai individu maupun masyarakat dan bangsa. Jatuh bangunnya suatu bangsa tergantung pada bagaimana etika masyarakat yang menghuninya.

Manusia dibekali akal pikiran yang berguna untuk membedakan antara yang hak dan yang batil, baik buruk, dan hitam putihnya dunia. Selamat dan tidaknya manusia, tenang dan 


\section{Yazidul Busthomi, Syamsul A’dlom}

resahnya manusia tergantung pada akhlaqnya. Akhlaq mampu mengantarkan manusia untuk menjalankan fungsinya sebagai hamba Allah dan kholifah di muka bumi untuk membangun dunia dengan konsep yang ditetapkan oleh Allah. Akhlak merupakan bagian yang tidak bisa dipisahkan dari kehidupan manusia dan mampu membedakan manusia dengan makhluk lainnya di muka bumi.

Akhlaq dalam pendidikan Islam merupakan hal yang sangat penting, baik secara konseptual maupun praktis. Dalam pendidikan akhlaq terkandung normatif keislaman dan teladan dari tokoh penebar kebaikan yang menjadi pondasi yang vital dalam membentuk manusia yang berakhlaq mulia. Dan nantinya mampu menempatkan tingkah lakunya secara arif dan bijaksana serta didukung pengetahuan keislaman yang mendalam. Islam memiliki perhatian terhadap masa-masa pertumbuhan manusia sejak kecil, remaja, dewasa, dan pada saat memiliki tanggung jawab sepenuhnya baik terhadap dirinya maupun keluarganya, yang mana perhatian Islam ini berupa pendidikan akhlaq yang dibimbingkan kepada manusia.

Dalam dunia pendidikan selain peran sekolah dan pendidik, peran orang tua sangat penting dalam memberikan sentuhan pendidikan kepada anak. Kedua orang tua bertanggung jawab dalam memberikan keteladanan dalam bentuk sikap dan perilaku sehari-hari karena orang tua adalah pihak yang paling dekat dengan lingkungan anak. Pendidik dalam dunia pendidikan adalah prioritas. Untuk melaksanakan tugas daalm meningkatkan proses belajar mengajar, pendidik menempati kedudukan sebagi figur. Di tangan pendidiklah terletak kemungkinan berhasil atau tidaknya pencapaian tujuan belajar mengajar di sekolah, serta bergantungnya masa depan karir para peserta didik yang menjadi tumpuan para orang tuanya. Pendidik juga harus menanamkan nilai-nilai iman dan akhlaq yang mulia.

Pendidikan akhlaq adalah pendidikan mengenai dasar-dasar akhlaq dan keutamaan perangai, tabiat yang harus dimiliki dan dijadikan kebiasaan oleh anak sejak masa analisa sampai ia menjadi seorang mukallaf, seseorang yang telah siap mengarungi lautan kehidupan. Ia tumbuh dan berkembang dengan berpijak pada landasan iman kepada Allah dan terdidik untuk selalu kuat, ingat bersandar, meminta pertolongan dan berserah diri kepada-Nya, maka ia akan memiliki potensi dan respon yang instingtif di dalam menerima setiap keutamaan dan kemuliaan. Di samping terbiasa melakukan akhlaq mulia.

Pendidikan akhlaq bertujuan untuk menumbuhkan pembentukan kebiasaan berakhlaq mulia dan beradat kebiasaan yang baik. Memantapkan rasa keagamaan pada peserta didik, 
membiasakan diri berpegang pada akhlaq mulia dan membenci akhlaq yang rendah. Membiasakan peserta didik bersikap rela, optimis, percaya diri, tahan menderita dan sabar. Membimbing peserta didik ke arah sikap yang sehat dan dapat membantu mereka berinteraksi sosial yang baik, mencintai kebaikan untuk orang lain, suka menolong, sayang kepada yang lemah, dan menghargai orang lain. Membiasakan peserta didik bersopan santun dalam berbicara dan bergaul baik di sekolah maupun di luar sekolah. Selalu tekun beribadah dan mendekatkan diri kepada Allah dan bermuamalah yang baik. Tujuan pendidikan akhlaq bukan hanya mengetahui teori, akan tetapi membentuk hidup yang menteladani akhlaq baginda Rasulullah saw serta memberi manfaat kepada sesama manusia.

\section{Pengertian Etika}

Menurut istilah bahasa etika berasal dari kata ethos yang berarti adat istiadat (kebiasaan), sedangkan secara istilah etika adalah ilmu yang mempelajari tingkah laku manusia untuk menentukan nilai-nilai perbuatan baik buruk, sedangkan ukuran untuk menetapkan nilainya adalah akal pikiran manusia atau resio. Etika adalah suatu keseluruhan norma dan penilaian yang digunakan oleh masarakat yang bersangkutan untuk mengetahui bagaimana manusia seharusnya manjalankan hidupnya mengenai suatu cara yang rasional (Ahmad Syukri, 2007, p.113). Etika berfungsi sebagai penilai, penentu, penetap terhadap suatu perbuatan yang dilakukan oleh manusia, dengan demikian etika lebih berperan sebagai konseptor terhadap perilaku yang dilakukan oleh manusia. Selain itu etika bersifat relatif yang dapat berubah-ubah sesuai dengan tuntutan zaman.

Istilah etika sering disamakan dengan istilah moral, budi pekerti dan akhlaq, yang mana istilah-istilah tersebut memang mempunyai sifat yang sama yaitu memberi orientasi sebagai petunjuk kehidupan manusia. Berikut adalah penjelasan untuk membedakan istilah- istilah tersebut:

1) Moral

Moral secara etimologi berasal dari bentuk jamak yaitu mos yang berarti adat kebiasaan. Sedangkan secara terminologi moral berarti suatu istilah yang digunakan untuk menentukan batas-batas dari sifat, peranggai, kehendak, pendapat atau perbuatan yang secara layak dapat dikatakan benar, salah, baik, buruk. Dan yang dimaksud orang yang bermoral adalah yang dalam tingkah lakunya selalu baik dan benar. Tolak ukur moral adalah norma-norma yang tumbuh dan berkembang di dalam masyarakat. Moral juga diartikan 


\section{Yazidul Busthomi, Syamsul A'dlom}

sebagai sesuatu yang sesuai dengan ide-ide yang umum diterima tentang tindakan manusia yang baik dan wajar dan diterima oleh kesatuan atau lingkungan tertentu. Moral berarti bagaimana seseorang memiliki makna tentang bagaimana perilaku yang sesuai dengan norma atau nilai yang diakui oleh individu atau kelompok. Nilai-nilai tersebut diyakini oleh masarakat sebagai yang memberikan harapan munculnya kebahagiaan dan ketentraman. Nilai tersebut ada yang berkaitan dengan perasaan wajib, rasional, berlaku umum dan jika nilainilai tersebut telah mendarah daging lama kelamaan akan muncul kesadaran moral.

2) Budi Pekerti

Budi pekerti juga sering digunakan sebagai istilah akhlak, yang mana budi diartikan sebagai alat batin untuk menimbang dan menentukan mana yang baik dan buruk, budi adalah hal yang berhubungan dengan kesadaran yang didorong oleh pemikiran atau yang disebut karakter, sedangkan pekerti ialah perbuatan manusia yang terlihat karena terdorong oleh perasaan hati atau disebut juga dengan behavior. Selain itu dinyatakan bahwa budi pekerti berinduk pada etika, yang mana secara hakiki adalah perilaku, dan budi pekrti berisi perilaku manusia yang akan diukur menurut kebaikan dan keburukanya melalui norma agama, norma hukum, tata krama dan sopan santun, norma budaya dan adat istiadat masyarakat.

Hubungan antara akhlaq dengan etika, moral dan budi pekerti dapat dilihat dari fungsi dan perananya yang sama-sama menentukan hukum atau nilai dari satu perbuatan yang dilakukan oleh manusia dari aspek baik dan buruknya, benar dan salahnya, yang sama-sama bertujuan untuk menciptakan masyarakat yang damai, tentram, sejahtera secara lahir dan batin. Perbedaan dan keterkaitan antara akhlaq dengan etika, moral dan budi pekerti mempunyai sumber dan titik mulai yang beragam yaitu wahyu, akal, dan adat istiadat atau kebiasaan.

3) Akhlaq

Dilihat dari sudut etimologi perkataan “Akhlaq“ ( أَخْلاقَقُ ) berasal dari bahasa Arab jama' dari "Khuluqun“ ( خُلُقٌ ) yang menurut lughat diartikan adat kebiasaan, tabi'at, watak, adab/sopan santun. Khuluq merupakan gambaran sifat batin manusia, gambaran bentuk lahiriah manusia. Separti raut wajah, gerak anggota badan dan seluruh tubuh (Yatimin Abdullah, 2007, p.3). 
Pengertian akhlaq secara terminologi, para ahli berbeda pendapat, namun memiliki kesamaan makna yaitu tentang perilaku manusia. Pendapat para ahli sebagai berikut:

1) Abdul Hamid mengatakan, akhlaq ialah ilmu tentang keutamaan yang harus dilakukan dengan cara mengikutinya sehingga jiwanya terisi dengan kebaikan, dan tentang keburukan yang harus di hindarinya sehingga jiwanya kosong (bersih) dari segala bentuk keburukan.

2) Imam Al- Ghazali mengatakan, akhlaq ialah sifat yang tertanam dalam jiwa yang menimbulkan bermacam-macam perbuatan dengan gampang dan mudah, tanpa memerlukan pemikiran dan pertimbangan.

3) M. Abdullah Daraz, mendefinisikan akhlaq sebagai suatu kekuatan dalam kehendak yang mantap, kekuatan kombinasi membawa kecenderungan pada pemilihan pihak yang benar (akhlaq baik) atau pihak yang jahat (akhlaq buruk).

4) Ibnu Maskawaih, mendefinisikan akhlaq sebagai suatu keadaan yang melekat pada jiwa manusia, yang berbuat dengan mudah, tanpa melalui proses pemikiran atau pertimbangan (kebiasaan sehari- hari).

5) Ahmad Amin berpendapat bahwa, budi adalah suatu sifat jiwa yang tidak kelihatan, adapun akhlaq yang kelihatan itu adalah kelakuan atau muamalah. Namun perbuatan yang hanya dilakukan satu atau dua kali tidak menunjukan akhlaq (Ahmad Amin, 2001, p.63).

Jadi khuluq (budi pekerti) atau akhlaq ialah suatu kondisi atau sifat yang telah merasap kedalam jiwa dan menjadi suatu kepribadian yang menimbulkan berbagai macam perbuatan dengan cara spontan tanpa melakukan pemikiran sebelumnya. Akhlaq adalah ilmu yang mengajarkan manusia berbuat baik, dan mencegah perbuatan jahat dalam pergaulannya dengan Tuhan, manusia, dan makhluk sekelilingnya dalam kehidupan seharihari sesuai dengan nilai- nilai moral dan nilai-nilai norma agama.

\section{Definisi Guru dalam Pendidikan Islam}

Guru dalam pendidikan Islam ialah siapa saja yang bertanggung jawab terhadap perkembangan anak didik. Dalam Islam, orang yang bertanggung jawab tersebut adalah orang tua dari anak didik. Tanggung jawab itu disebabkan sekurang-kurangnya oleh dua hal: pertama karena kodrat, yaitu karena orang tua ditakdirkan menjadi orang tua anaknya, dan karena itu ia 


\section{Yazidul Busthomi, Syamsul A'dlom}

ditakdirkan pula bertanggung jawab mendidik anaknya, kedua karena kepentingan kedua orang tua, yaitu orang tua berkepentingan terhadap kemajuan perkembangan anaknya, sukses anaknya adalah sukses orang tua juga. Tanggung jawab pertama dan utama terletak pada orang tua (Ahmad Tafsir, 2014, p.74).

Sama dengan teori pendidikan Barat, tugas guru dalam pandangan Islam secara umum adalah mendidik, yaitu mengupayakan perkembangan seluruh potensi anak didik, baik potensi psikomotor, kognitif, maupun potensi afektif. Potensi itu harus dikembangkan secara seimbang sampai ke tingkat setinggi mungkin, menurut ajaran Islam. Karena orang tua adalah pendidik pertama dan utama, maka inilah tugas orang tua tersebut.

Pada awalnya tugas itu adalah murni tugas kedua orang tua, jadi tidak perlu orang tua mengirimkan anaknya ke sekolah. Akan tetapi, karena perkembangan pengetahuan, keterampilan, sikap, serta kebutuhan hidup sudah sedemikian luas, dalam, dan rumit, maka orang tua tidak mampu lagi melaksanakan sendiri tugas-tugas mendidik anaknya. Selain tidak mampu karena luasnya perkembangan pengetahuan dan keterampilan, mendidik anak di rumah sekarang ini amat tidak ekonomis. Cobalah bayangkan, seandainya orang tua mendidik anaknya sejak tingkat dasar sampai perguruan tinggi, di rumah, oleh dirinya sendiri, sekalipun katakanlah orang tua mampu menyelenggarakan itu, apa yang akan terjadi ? Mahal, tidak efisien, dan mungkin juga tidak akan efektif.

Pada zaman yang telah maju ini semakin banyak tugas orang tua sebagai pendidik yang diserahkan kepada sekolah. Itu lebih murah, lebih efisien, dan juga lebih efektif. Sekalipun demikian, secara teoritis sekolah dan rumah tangga seharusnya tetap menyadari sejarah pendidikan tersebut. Kesadaran itu akan mengingatkan orang tua dan sekolah tentang perlunya dijalin kerja sama sebaik-baiknya antara sekolah dan rumah tangga. Kerja sama itu dimulai sejak perencanaan, pelaksanaan, dan evaluasi pendidikan.

Pengaruh pendidikan di dalam rumah tangga terhadap perkembangan anak memang amat besar, mendasar, mendalam. Akan tetapi, pada zaman modern ini pengaruh itu boleh dikatakan terbatas pada perkembangan aspek afektif, yaitu perkembangan sikap. Pengaruh pendidikan di sekolah juga besar dan luas serta mendalam, tetapi hampir-hampir hanya pada segi perkembangan aspek kognitif (pengetahuan) dan psikomotor (keterampilan). Pengaruh yang diperoleh anak didik di sekolah hampir seluruhnya berasal dari guru yang mengajar di kelas. Jadi, guru yang dimaksud di sini adalah pendidik yang memberi pelajaran kepada murid, 
biasanya guru adalah pendidik yang memegang mata pelajaran di sekolah (Ahmad Tafsir, 2014, p.75).

Dalam dunia pendidikan selain peran sekolah dan pendidik, peran orang tua sangat penting dalam memberikan sentuhan pendidikan kepada anak. Kedua orang tua bertanggung jawab dalam memberikan keteladanan dalam bentuk sikap dan perilaku sehari-hari karena orang tua adalah pihak yang paling dekat dengan lingkungan anak. Pendidik dalam dunia pendidikan adalah prioritas. Untuk melaksanakan tugas dalam meningkatkan proses belajar mengajar, guru menempati kedudukan sebagai figur. Di tangan gurulah terletak kemungkinan berhasil atau tidaknya pencapaian tujuan belajar mengajar di sekolah, serta bergantungnya masa depan karir para peserta didik yang menjadi tumpuan para orang tuanya. Guru juga harus menanamkan nilai-nilai iman dan akhlaq yang mulia.

Pendidikan merupakan suatu sistem dan proses yang melibatkan berbagai komponen. Dalam merumuskan tujuan ada beberapa prinsip yang harus diperhatikan. Prinsip-prinsip tersebut adalah sebagai berikut:

1. Prinsip universal, yaitu prinsip yang memandang keseluruhan aspek agama (aqidah, ibadah dan akhlaq serta muamalah), manusia (jasmani, rohani, dan nafsani), masyarakat dan tatanan kehidupannya, serta adanya jagad raya dan hidup,

2. Prinsip keseimbangan dan keserhanaan, keseimbangan antara berbagai aspek kehidupan dan kebutuhan,

3. Prinsip kejelasan, prinsip yang di dalamnya terdapat ajaran dan hukum yang memberikan kejelasan terhadap kejiwaan manusia,

4. Prinsip tidak bertentangan, antara komponen dengan komponen yang lain tidak bertentangan sehingga saling mendukung,

5. Prinsip realisme dan dapat dilaksanakan,

6. Prinsip perubahan yang diinginkan,

7. Prinsip menjaga perbedaan-perbedaan individu,

8. Prinsip dinamis dalam perubahan dan perkembangan yang terjadi dalam pelaku pendidikan, serta lingkungan dimana pendidikan itu dilaksanakan (Bukhari Umar, 2010, p.53).

Suatu hal yang ingin di wujudkan dalam proses pendidikan adalah kristalisasi berbagai nilai pribadi anak didik. Itulah yang disebut tujuan akhir. Tujuan akhir harus lengkap yang 


\section{Yazidul Busthomi, Syamsul A’dlom}

mencakup seluruh aspek, serta terintegrasi dalam pola kepribadian edial yang bulat dan utuh. Tujuan akhir mengandung nilai-nilai Islami dalam segala aspeknya, yaitu aspek normatif, aspek fungsional, dan aspek operasional. Dengan demikian jelas bahwa tujuan pendidikan Islam adalah mencapai keseimbangan pertumbuhan kepribadian manusia (anak didik) secara menyeluruh dan seimbang yang dilakukan melalui latihan jiwa, akal pikiran (intelektual), diri manusia yang profesional dan indra untuk menjadikannya insankamil yang memiliki kawasan kaffah agar mampu menjalankan tugas-tugas kehambaan dan kekhalifahan di muka bumi ini. Sedangkan menurut Abdurrahman al-Nahlawi tujuan pendidikan Islam adalah merealisasikan penghambaan kepada Allah dalam kehidupan manusia, baik secara individual maupun secara sosial (Abdurrahman An Nahlawi, 2015, p.117).

\section{Kedudukan Guru dalam Pendidikan Islam}

Salah satu hal yang amat menarik pada ajaran Islam ialah penghargaan Islam yang sangat tinggi terhadap guru. Begitu tingginya penghargaan itu sehingga menempatkan kedudukan guru setingkat di bawah kedudukan nabi. Penghargaan Islam terhadap Ilmu tergambar dari sebuah buku Asama Hasan Fahmi yaitu sebagai berikut:

1. Tinta Ulama' lebih berharga dari pada darah syuhada',

2. Orang berpengetahuan melebihi orang yang senang beribadah,

3. Apabila meninggal seorang alim, maka terjadilah kekosongan dalam Islam yang tidak dapat diisi kecuali oleh seorang alim yang lain (Ahmad Tafsir, 2014, p.76).

Dalam kitab-kitab hadis ditemukan banyak sekali hadis yang mengajarkan betapa tinggi kedudukan orang berpengetahuan biasanya dihubungkan pula dengan mulianya menuntut ilmu. Kedudukan orang alim dalam Islam dihargai tinggi bila orang itu mengamalkan ilmunya. Mengamalkan ilmu dengan cara mengajarkan ilmu itu kepada orang lain adalah suatu pengamalan yang dihargai oleh Islam. Al-Ghazali menjelaskan bahwa siapa yang memilih pekerjaan mengajar maka ia sesungguhnya telah memilih pekerjaan besar dan penting.

Sebenarnya tingginya kedudukan guru dalam Islam merupakan realisasi ajaran Islam itu sendiri. Islam memuliakan pengetahuan, pengetahuan itu didapat dari belajar dan mengajar, yang belajar adalah calon guru, dan yang mengajar adalah guru. Maka dalam ajaran Islam harus memuliakan guru. Tak terbayangkan terjadinya perkembangan pengetahuan tanpa adanya orang belajar dan mengajar, Tak terbayangkan adanya belajar dan mengajar tanpa adanya guru. Maka 
oleh karena itu, pantaslah kedudukn guru sangat mulia dalam pandangan Islam. Syarat-syarat Guru dalam Pandangan Islam

Soejono menyatakan bahwa syarat-syarat guru adalah sebagai berikut:

1. Tentang umur, harus sudah dewasa

Tugas mendidik adalah tugas yang amat penting karena menyangkut perkembangan seseorang, jadi menyangkut nasib seseorang. Oleh karena itu, tugas itu harus dilakukan secara bertanggung jawab. Itu hanya dapat dilakukan oleh orang yang telah dewasa, anak-anak tidak dapat dimintai pertanggung jawaban.

2. Tentang kesehatan harus sehat jasmani dan rohani

Jasmani yang tidak sehat akan menghambat pelaksana pendidikan, bahkan dapat membahayakan anak didik bila mempunyai penyakit menular. Dari segi rohani, orang gila berbahaya juga bila ia mendidik. Orang idiot tidak mungkin mendidik karena ia tidak akan mampu bertanggung jawab.

3. Tentang kemampuan mengajar ia harus ahli

Ini penting sekali bagi pendidik, termasuk guru. Orang tua di rumah sebenarnya perlu sekali mempelajari teori-teori ilmu pendidikan. Dengan pengetahuan itu diharapkan ia akan lebih berkemampuan menyelenggarakan pendidikan bagi anak-anaknya di rumah. Sering kali terjadi kelainan pada anak didik disebabkan oleh kesalahan pendidikan di dalam rumah tangga.

4. Harus berkesusilaan dan berdedikasi tinggi

Syarat ini penting dimiliki untuk melaksanakan tugas-tugas mendidik selain mengajar. Bagaimana guru akan memberikan contoh-contoh kebaikan bila ia sendiri tidak baik perangainya? Dedikasi tinggi tidak hanya diperlukan dalam mendidik selain mengajar, dedikasi tinggi diperlukan juga dalam meningkatkan mutu mengajar (Ahmad Tafsir, 2014, p.81).

Syarat-syarat menjadi guru yang baik adalah sebagai berikut:

1. Berijazah,

2. Sehat jasmani dan rohani,

3. Takwa kepada Tuhan dan berkelakuan baik,

4. Bertanggung jawab,

5. Berjiwa nasional (Ngalim Purwanto, 2007, p.139). 


\section{Yazidul Busthomi, Syamsul A’dlom}

\section{Sifat-sifat Guru dalam Pandangan Islam}

Sifat-sifat guru dalam pandangan Islam sebagai berikut:

1. Kasih sayang pada murid,

2. Senang memberi nasihat,

3. Senang memberi peringatan,

4. Senang melarang murid melakukan hal yang tidak baik,

5. Bijak dalam memilih bahan pelajaran yang sesuai dengan lingkungan murid,

6. Hormat pada pelajaran lain yang bukan pegangannya,

7. Bijak dalam memilih bahan pelajaran yang sesuai dengan lingkungan murid,

8. Mementingkan berfikir dan berijtihad,

9. Jujur dalam keilmuan,

10. Adil (Ahmad Tafsir, 2014, p.84).

Menurut al-Ghazali, terdapat beberpa sifat penting yang harus dimiliki oleh guru sebagai orang yang diteladani yaitu:
a. Amanah dan tekun bekerja,
b. Bersifat lemah lembut dan kasih sayang terhadap murid,
c. Dapat memahami dan berlapang dada dalam ilmu serta orang-orang yang mengajarkannya,
d. Tidak rakus pada materi,
e. Berpengetahuan luas,
f. Istiqamah dan memegang teguh prinsip (Ramayulis, 2008, p.207).

\section{Etika Guru Menurut Perspektif Pendidikan Agama Islam}

Etika guru menurut perspektif pendidikan agama Islam yaitu sebagai berikut:

1. Menerima pertanyaan yang diajukan oleh peserta didiknya dan sabar atas hal tersebut,

2. Tidak terburu-buru dalam segala urusan,

3. Duduk dengan penuh wibawa disertai ketenangan dan menundukkan kepala,

4. Tidak bersikap sombong kepada semua manusia, kecuali terhadap orang-orang yang dolim dan terang-terangan menunjukkan ke dolimannya untuk mencegah mereka berbuat dolim. Karena bersikap sombong terhadap orang-orang yang sombong adalah shadaqah seperti tawadu' terhadap orang-orang yang bersikap tawadu',

5. Mengutamakan tawadu' di tempat-tempat pertemuan dan majlis-majlis,

6. Tidak bermain dan bercanda, 
7. Menunjukkan kasih sayang kepada peserta didik di waktu mengajarnya dan bersabar terhadap peserta didik yang tidak pandai bertanya tetapi mengaku mengetahui sesuatu sedang ia tidak mengetahuinya, yaitu pendidik perlakukan dia dengan sikap dan perkataan yang baik,

8. Memperbaiki peserta didik yang bandel dengan bimbingan yang baik,

9. Tidak memarahi peserta didik yang bandel dan tidak menyindirnya,

10. Tidak sombong, tidak segan dan tidak malu mengatakan: "saya tidak tahu" atau mengatakan "wallahu a'lam", jika masalahnya tidak jelas atau tidak diketahui. Diriwayatkan dalam hadits bahwa seorang lelaki bertanya kepada Nabi SAW.: "Negeri mana yang paling buruk?" Nabi SAW. menjawab: "Saya tidak tahu, saya akan menanyakan kepada jibril". Jibril menjawab: "Saya tidak tahu. Saya akan menanyakan kepada Robbil izzah.

11. Memusatkan perhatian kepada penanya dan memahami pertanyaannya untuk menjawab masalahnya.

12. Menerima dalil yang benar dan mendengarkannya, meskipun dari lawan, karena mengikuti kebenaran adalah wajib.

13. Tunduk kepada kebenaran dengan kembali kepadanya ketika bersalah, sekalipun kebenaran itu dari orang lebih rendah kedudukannya.

14. Melarang peserta didik mempelajari ilmu yang membahayakan dalam agama seperti ilmu sihir, nujum dan ramal.

15. Melarang peserta didik dari mengharap selain ridha Allah dan negeri akhirat dengan ilmu yang berguna.

16. Mencegah peserta didik dari menyibukkan diri dengan fardhu kifayah sebelum menyibukkan diri dengan fardhu ain, sedangkan fardhu 'ainnya adalah memperbaiki lahir dan batinnya dengan ketakwaan, yaitu dengan menunaikan ibadah yang lahir dan batin dan menjauhi maksiat lahir dan batin.

17. Mengutamakan memperbaiki diri sendiri sebelum menyuruh orang lain berbuat kebaikan dan seblum melarang mereka berbuat kejahatan dengan bertakwa supaya diikuti amal perbuatan dan perkataannya oleh peserta didik (Zaid Husein, 2010, p.288). 


\section{Yazidul Busthomi, Syamsul A'dlom}

\section{Kesimpulan}

Menurut istilah bahasa etika berasal dari kata ethos yang berarti adat istiadat (kebiasaan), sedangkan secara istilah etika adalah ilmu yang mempelajari tingkah laku manusia untuk menentukan nilai-nilai perbuatan baik buruk, sedangkan ukuran untuk menetapkan nilainya adalah akal pikiran manusia atau resio. Etika adalah suatu keseluruhan norma dan penilaian yang digunakan oleh masarakat yang bersangkutan untuk mengetahui bagaimana manusia seharusnya manjalankan hidupnya mengenai suatu cara yang rasional. Etika berfungsi sebagai penilai, penentu, penetap terhadap suatu perbuatan yang dilakukan oleh manusia, dengan demikian etika lebih berperan sebagai konseptor terhadap perilaku yang dilakukan oleh manusia.

Di antara etika guru menurut perspektif pendidikan agama Islam yaitu:1. Menerima pertanyaan yang diajukan oleh peserta didiknya, 2. Tidak terburu-buru dalam segala urusan, 3. Duduk dengan penuh wibawa disertai ketenangan dan menundukkan kepala, 4. Tidak bersikap sombong kepada semua manusia, 5. Mengutamakan tawadu' di tempat-tempat pertemuan dan majlis-majlis, 6. Tidak bermain dan bercanda, 7. Menunjukkan kasih sayang kepada peserta didik di waktu mengajarnya.

\section{Daftar Rujukan}

Abdurrahman An Nahlawi. 2015. Pendidikan Islam di Rumah, Sekolah dan Masyarakat. Jakarta: Gema Insani.

Ahmad Amin. 2001. Etika (Ilmu Akhlak). Cetakan VI Jakarta: Bulan Bintang.

Ahmad Tafsir. 2014. Ilmu Pendidikan dalam Perspektif Islam. Bandung: PT Remaja Rosdakarya.

Arifin, Muzayyin. 2018. Kapita Selekta Pendidikan Islam. Cetakan III. Jakarta: PT Bumi Aksara. Bukhari Umar. 2010. Ilmu Pendidikan Islam. Jakarta: Amzah.

Engkoswara dan Aan Komariah. 2015. Admistrasi Pendidikan. Cetakan I. Bandung: Alfabeta.

Ismail. 2019. Strategi Pembelajaran Agama Islam Berbasis PAIKEM. Cetakan IV. Semarang: Rasail Media Group.

Jalaluddin. 2017. Psikologi Agama. Jakarta: PT Rajagrafindo Persada.

Nawawi, Muhammad. 2010. Maroqil Ubudiyah, diterjemahkan oleh Zaid Husein, Terjemah Maroqil Ubudiyah. Cetakan I. Surabaya: Mutiara Ilmu. 
Ngalim Purwanto. 2007. Ilmu Pendidikan Teoretis dan Praktis. Bandung: PT Remaja Rosdakarya.

Nizar, Samsul. 2018. Sejarah Pendidikan Islam. Cetakan II. Jakarta: Kencana Prenada Media Group.

Ramayulis. 2008. Ilmu Pendidikan Islam. Cetakan VII. Jakarta: Kalam Mulia.

Subhan Adi Santoso, Maulidyah Amalina Rizqi. 2020. Kinerja Pengawas Sekolah, Kepala Sekolah, dan Guru pada Pendidikan. Yogyakarta: Deepublish

Soetjipto dan Raflis Kosasi. 2019. Profesi Keguruan. Cetakan IV. Jakarta: PT Rineka Cipta.

Syah, Muhibbin. 2018. Psikologi Pendidikan dengan Pendekatan Baru. Cetakan XIIII. Bandung: PT Remaja Rosdakarya.

Tirtarahardja, Umar dan La Sulo. 2015. Pengantar Pendidikan. Cetakan II. Jakarta: PT Rineka Cipta.

Yatimin Abdullah. 2007. Penagantar Studi Etika. Jakarta: Raja Grafindo Persada.

Zuhairini . 2015. Filsafat Pendidikan Islam. Cetakan II. Jakarta: Bumi Aksara. 
Yazidul Busthomi, Syamsul A'dlom

280 Volume 7 No. 2 , 1 September 2021 